\title{
Green energy security assessment in Morocco: green finance as a step toward sustainable energy transition
}

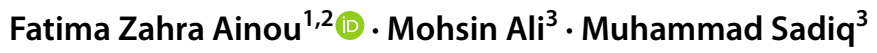 \\ Received: 24 August 2021 / Accepted: 6 February 2022 \\ (c) The Author(s), under exclusive licence to Springer-Verlag GmbH Germany, part of Springer Nature 2022
}

\begin{abstract}
Morocco is an energy-deficient country depending on almost $94 \%$ of energy imports to fuel its growing economy. Due to its fast-growing population, Morocco's energy consumption is projected to increase significantly, adding more pressure on the energy system. On the other hand, the rising tension of scarcity of resources, energy price fluctuations, and environmental issues have all made energy security one of its top priorities. Therefore, Morocco launched the National Energy Strategy (NES) in 2009 to reach $42 \%$ renewable generation by 2020, which was renewed to up to $52 \%$ by 2050 . This study analyzes Morocco's energy security under the 4-As framework from 2000 to 2016.The 4-As methodology aims to assess and graphically illustrate the changes in Morocco's energy security by mapping these changes into four key dimensions: the availability of energy resources, the applicability of technology, the acceptability by the environment and society, and the affordability of energy resources. The quantitative analysis shows that Morocco's energy security performance was at its optimum during the first period of study (2000-2004) but then regressed for the remainder of the study period, as energy imports and prices increased, in addition to the low performance in applicability characterized by low energy efficiency. To improve Morocco's energy security status and move toward a sustainable energy transition, this study suggests integrating a higher share of renewable energy into the energy mix and boosting efficient technologies through a large scale of green finance and green investment projects.
\end{abstract}

Keywords Morocco $\cdot$ Green energy security $\cdot 4$-As framework $\cdot$ Indicator system $\cdot$ Renewable energy $\cdot$ Energy transition $\cdot$ Green finance

\section{Introduction}

The philosophy of energy security differs significantly between classical and contemporary studies. For years, the definition of an all-inclusive concept of energy security has

Responsible Editor: Ilhan Ozturk

Fatima Zahra Ainou

fatimaz.ainou@yahoo.com

1 School of Management and Economics, Beijing Institute of Technology, Beijing 100081, China

2 Center for Energy and Environmental Policy Research (CEEP), Beijing Institute of Technology, Beijing 100181, China

3 School of Accounting and Finance, Faculty of Business and Law, Taylor's University, 1, Jalan Taylor's, Subang Jaya, Selangor, Malaysia been a topic of debate. Specifically, a concept that includes all the necessary economic, technological, and environmental issues to analyze a country's energy security comprehensively is needed.

The energy security concept has evolved into a multidimensional concept that is not confined to the old classical view of solely "oil reserves" as energy security. The concept has instigated researchers, policymakers, and leaders worldwide to start looking into its complexity, with a broader spectrum of related items being expanded day by day. Numerous studies seeking a definition of energy security using different elements were involved. "Sufficient and reliable supply of fossil fuels at an affordable price" was the most dominant definition in energy security studies (Colglazier and Deese 1983; Yergin 1988; Yao and Chang 2014; Asia Pacific Energy Research Centre - APERC 2007; IEA 2019). By observing these three elements constituting this definition, two main dimensions-economics and 
technology-were revealed and strongly presented while conceptualizing energy security. Following the climatic and environmental challenges with global warming and excessive $\mathrm{CO}_{2}$ emissions, environmental issues such as clean air, clean water, and a healthy landscape were also considered while defining energy security. Many international organizations and academic studies have given a strong focus on the environment as an essential element determining the energy security concept (Asia Pacific Energy Research Centre APERC 2007; European Commisson 2001; Vivoda 2010; Sovacool and Mukherjee 2011).

The Asia Pacific Energy Research Centre (APERC 2007) introduced the A-framework of energy security, merging the classical-Availability, Affordability with Accessibility and Acceptability - as critical dimensions to analyze and structure their reports on energy security in Asia. Kruyt et al. (2009) identified four main dimensions of energy security that interpreted the availability, accessibility, affordability, acceptability of energy for the analysis, and projection of energy security in Western Europe. Vivoda (2010) established an energy security assessment instrument consisting of eleven dimensions connected with the current global energy system to evaluate the energy security of individual states or regions. Von Hippel et al. (2011) suggested a framework of six dimensions to analyze different energy scenarios in East Asia. Hughes (2012) used three dimensions (availability, affordability, and acceptability) as a common structure to explain and analyze energy security. Sovacool (2013) presented an index system to measure the national performance on energy security over time. The author applied interconnected factors (dimensions) of availability, affordability, efficiency, sustainability, and governance across 18 countries, taking Japan, Laos, and Myanmar as case studies. Yao and Chang (2014) developed a framework for evaluating energy security and proposed four essential dimensions to examine changes in China's energy security from 1980 to 2010 . The framework included the availability of energy resources, the applicability of technology, acceptability of society, and the affordability of energy resources reflecting economics, technological, and environmental elements. Their study's main findings indicated that China's energy security was on a downward trend during the FiveYear Plan (FYP) period (2006-2010). They suggested the need to develop renewable energy in the country on a large scale considering environmental objectives. Incorporating Yao and Chang's framework, Tongsopit et al. (2016) examined the energy security status of the Association of Southeast Asian Nations (ASEAN) between 2005 and 2010 by applying the 4-As framework. The authors found that the ASEAN region had made little progress toward achieving energy security in terms of the applicability of technology but regressed in other energy security dimensions in the previous FYP period (2005-2010). Increasing the development of renewable energy and adopting energy efficiency technologies were also highlighted for the ASEAN region to achieve energy security and sustainable energy policy targets.

All these classical and contemporary studies indicate that the concept of energy security is dynamic and adaptable, yet there is no universal definition that can determine energy security; from our point of view, energy security should better consist of available energy resources at affordable prices, with applicable technologies to utilize and harness energy resources in an environmentally acceptable manner (Yao and Chang 2014).

During our review of the available literature on energy security in Africa, only a few academic publications addressing energy security issues were found. For instance, Sebitosi (2008) examined policies and measures related to energy efficiency in some countries and how the lessons learned in the context of security of supply and environment could be applied in South Africa. In addition to this, Mitigation Action Plans and Scenarios (MAPS) (Trollip et al. 2014) launched their report on energy security in South Africa, uncovering threats and challenges that the country's energy system was facing. The energy security implementation was found to be misguided. Therefore, the analysis of the country's energy system resilience and challenges to its integrity was crucial. To highlight the causes of the energy security crisis and mitigate the risks in South Africa, the authors emphasized the urgent need for a multi-disciplinary approach for informative policy research. To enhance energy cooperation across the Mediterranean, Lacher and Kumetat (2011) discussed the potential threats and challenges of energy security in North Africa. According to the authors, necessary measures need to be taken to deal with the intentional disruption of energy supplies by governments and attacks by non-state actors on the energy infrastructure. Alemzero et al. (2021) propose a composite measure of energy security in Africa to examine its impacts and trends using a sample of 28 African countries from 2000 to 2018 , including Morocco. The main findings point to a pattern of energy insecurity in the countries investigated.

Concerning Morocco, only a few studies have addressed energy security issues in the country. Morocco being an emerging economy has not been assessed with a wider holistic research lens. The present studies have discussed energy security in Morocco from sustainable development and environment protection point of view. For instance, Karakosta et al. (2013) emphasized the need to promote renewable energy sources (RES) in Middle Eastern and North African (MENA) countries. Morocco was used as a case study to support its National Energy Strategy, strengthen energy security, and reduce GHG emissions. Kousksou et al. $(2015 \mathrm{a}, \mathrm{b})$ focused mainly on developing renewable energy projects and enhancing energy efficiency to achieve Morocco's energy security goals. In contrast, Moore (2017) 
focused on the interdependency and the regional electricity integration aspects to salve the country's energy security issues.

Due to its dynamic nature (Ang et al. 2015), addressing the paradigm shifts of energy security is crucial and requires a comprehensive assessment framework to cope with its complexity. For Morocco, we observed that these studies primarily looked at Moroccan energy security from an environmental and technological perspective only. However, the immensely important economic aspect of energy security in Morocco, such as the affordability of energy prices, particularly pertinent to imported fuel prices and electricity prices, has not yet been discussed so far. The findings from existing literature indicate preliminary studies addressing only limited issues of Morocco's energy security, and lack of a comprehensive analysis covering all essential aspects of energy security in the country.

Considering Morocco's energy dependency rate that has reached approximately $94 \%$ in 2016 , this heavy external dependency is causing current and future threats and challenges. Therefore, the Moroccan energy system is more vulnerable to the risk of putting the national budget under a heavy financial burden due to the rising cost of energy importation. To solve these challenges and respond to these risks in line with the National Energy Strategy (NES) targets for future energy security, this study seeks to assess energy security in Morocco comprehensively, taking all the necessary aspects of energy security into account. By drawing upon the developed framework by Yao and Chang (2014), which focuses on a handful of essential dimensions to provide a holistic assessment of China's energy security. Taking leads from their holistic multi-dimensional approach, our suggested framework for Morocco is a comprehensive and interdisciplinary framework based on an indicator system that provides a significant and rigorous assessment of Morocco's energy security. Specifically, our contributions in the pertinent realm of literature are as follows: (i) provide an interdisciplinary energy security assessment that covers four key dimensions: availability, applicability, acceptability, and affordability, which reflect the economic, technological, and environmental aspects; (ii) describe trends and changes of energy security, analyze the energy security performance during the past 17 years, and identify the key challenges faced by the country's energy system; (iii) examine all aspects needed for Morocco to reduce the heavy dependency on foreign fossil fuels and achieve energy security goals, in turn, our study anticipates supporting the national policy by assisting policymakers and key players in tracking the progress toward energy security objectives. Overall, our proposed systematic framework for Morocco is, to the best of our knowledge, the first study to analyze Morocco's energy security using this comprehensive method which is gaining prominence among energy security assessment studies. The remaining of our study is organized as follow: the "Data and methodology" section presents dimensions and indicators' classifications along with the assessment methods; the "Results and discussions" section describes our results and discussions; the "Conclusions and policy implications" bring up conclusions, policies, limitations, and future directions.

\section{Data and methodology}

\section{The 4-As framework}

Based on the existing definition of energy security stated in the previous section, we define the following four major energy security dimensions-availability, applicability, acceptability, and affordability. The selected indicators employed in each dimension are presented in Appendix Table 6.

Availability The availability is the sufficient supply of energy underlined by the values of independence and diversification. In an interview, the Moroccan government representatives emphasized the importance of energy independence and diversification for the country's energy security to meet the growing demand (Moore 2017). The country's abundant renewable energy resources such as wind and solar (Kousksou et al. 2015a, b) could help promote the diversification of the energy mix and balance the energy supply of different fuel types.

Conventional energy sources, such as oil, gas, and coal, are exhaustible in the long run (Hotelling 1931). However, the renewable energy sources that are abundantly available in nature compete with conventional energy sources. Therefore, an appropriate indicator system will assist with the evaluation of the energy availability of the country. This paper measures Morocco's energy security performance on the availability dimension through the following indicators: AV-1: share of oil import in oil supply; AV-2: share of gas import in gas supply; AV-3: share of coal import in coal supply; AV-4: share of RE in power generation; AV-5: share of PSH in power generation; AV-6: share of electricity import in total electricity supply.

The higher the share of energy imports such as oil, gas, coal, and electricity imports, the lower the availability dimension. On the other hand, the higher the share of RE in power generation, the greater the energy availability.

Applicability The applicability dimension reflects the country's ability to adopt new technologies to exploit indigenous energy reserves further, ensure energy efficiency and conversation for the remaining hydrocarbon reserves, and make greater use of renewable energy resources (Chang and $\mathrm{Li}$ 
2015). For instance, the adoption of new technologies and availability of high-quality infrastructure will reduce energy loss during electric power generation, increase energy conservation to maintain energy use productivity, and enhance economic growth and efficiency for output with less energy input.

Following the NES objectives, the national plans of promoting domestic renewable energy sources and improving energy efficiency (Law $n^{0} 47-09,2011$ ) (Kousksou et al. 2015a, b) are national priorities to make better use of energy, thereby lowering the energy bills and contributing to sustainable development. The country aims to increase energy efficiency to achieve $12 \%$ on energy saving by 2020 and $15 \%$ by 2030 (IEA 2019). The applicability dimension can serve as an index to support the technological development of renewable and non-renewable energy through the innovation and adoption of new infrastructure. Applicability could be reflected explicitly in the following indicators:

AP-1: Fossil fuel power plant consumption is an indicator used by the Ministry of Energy, Mines, Water and Environment (MEMEE) as another way to measure the efficiency of installed thermal power generation capacity (how large of electricity loads a thermal power generator can handle), as well as the efficiency of energy production from fossil fuels. More specifically, it indicates, on average, the amount of fossil fuel required to produce 1 GWh of final energy using its installed thermal energy production capacity (MEMEE 2013). Fossil fuel power plant consumption depends on three types of fuels: oil, gas, and coal. The total electricity generated from these power plants does not include hydroelectric systems or other renewable energy technologies.

AP-2: Electricity production efficiency is the ratio of electricity generated by power plants (all technologies combined) and the total input of primary and secondary energy into power plants in terms of energy consumption. The efficiency of electricity generation measures the entire sector's performance on energy production, including all kinds of technologies and resources (conventional and renewables). It allows seeing the impact of other electricity generation forms, such as renewable technologies, on the total cost of electricity generation. In other words, an increase in renewable energy production enriches entire electricity generation and reduces the total cost of fossil fuels used in thermal power plants.

AP-3: Fossil fuel consumption in electricity production. This is the same concept as the fossil fuel power plant consumption except that electricity produced with renewable or hydroelectric energies is included. An increase in power generation from renewables will help decrease fossil fuel consumption in electricity production that is the possibility of becoming independent from external resources. This step will require significant changes in the energy mix of the power plant as well as economic infrastructure, so the high effect of the integration of renewables in power generation might be more visible in the longer term.

AP-4: No. of exploratory wells drilled for oil and gas Morocco's energy sector is mostly dominated by oil, which plays a significant and growing role in the energy mix. In 2016, crude oil imports reached $99.76 \%$ of the total oil supply. This heavy dependency on external resources and high energy import bills provides a strong motive for the country to promote and maintain exploration and drilling activities for indigenous oil and gas. This will increase the likelihood of finding remarkable reserves. Such an action plan will help reduce the oil demand and bring significant benefits to Morocco's energy security.

AP-5: Energy intensity is a measure used to assess the energy efficiency of a particular economy (MEMEE 2013). Technically, energy efficiency can be reflected in lower energy consumption while maintaining economic activities and services in the same level. This study measures the amount of energy used per unit of GDP produced in Morocco. An increase in the energy intensity ratio would indicate higher energy consumption. The cumulative impact of all energy efficiency technologies in a particular economy can be measured by the status of energy intensity or energy efficiency (Yao and Chang, 2014; Gallagher 2006). Actions taken to reduce energy intensity will bring significant energy efficiency benefits and help the country meet the energy security and emission reduction targets.

Acceptability The acceptability refers to environmental and social aspects (Kruyt et al. 2009). This dimension illustrates how an economy's production and utilization can be achieved concerning societal and ecological impacts. With rising issues of global warming and air quality, much attention is given to environmental problems and the adoption of eco-friendly solutions. Due to the change in energy structure from a high-carbon to a low-carbon energy system, the energy transition has become one of the Moroccan NES priorities as a roadmap that reconciles economic development, and societal and environmental objectives. It promotes a high share of renewable electricity. Environmentally friendly sources such as wind and solar, which currently require soft financing, provide significant strategic benefits such as reduction in fuel import bills and diversification in power supply. Besides their benefits to the economy, renewable technologies can also substitute electricity import hence improving energy security and reducing $\mathrm{CO}_{2}$ emissions. 
Adopting these new sources of energy should meet the social and environmental criteria (Tongsopit et al. 2016). Diversifying Morocco's energy mix by integrating a high share of renewables would improve its energy security and serve for $\mathrm{CO}_{2}$ emission reduction.

Morocco has a $42 \% \mathrm{CO}_{2}$ emission reduction target, committed to reducing GHG emissions across the entire economy by 2030 . The reduction comprises $17 \%$ below business as usual (BAU) levels and an additional $25 \%$ conditional on international support. This was stated under the ratified Paris Agreement during the COP-22, outlined in the Nationally Determined Contribution (NDC), and submitted to UNFCCC in 2016 (Morocco 2016).

This study measures Morocco's acceptability performance through the following indicators: AC-1: the share $\mathrm{RE}$ in power generation; $\mathrm{AC}-2$ : $\mathrm{CO}_{2}$ emissions per capita; AC-3: share of global $\mathrm{CO}_{2}$ emissions.

In Morocco, the power sector is the primary driver of $\mathrm{CO}_{2}$ emissions, which accounts for $39 \%$, followed by the transport sector with $31 \%$ of the total emissions. The rest is covered by industries (13\%), residential and commercial buildings (12\%), and agriculture (5\%) (IEA 2019).

Affordability The affordability refers to the previous definition of energy security mentioned before in our study, "The availability of sufficient supplies at affordable prices" (Yergin 2011). According to Yao and Chang (2014), affordability consists of three features: reasonable and stable energy price, equitable access to energy resources and services, and high quality of energy resources. The affordability of energy prices alongside the national budget's financial stability is now a significant concern of the Moroccan government. For private domestic use, electricity tariffs are distinguished according to six household bands of monthly consumption levels within the social tariff scheme. These prices are typically regulated between 0.9 and 1.59 MAD per kWh (ONEE 2017). These prices (tariffs) mostly remain below the generation cost. This study refers to the international prices of imported fossil fuels and domestic retail prices for electricity to reflect Morocco's energy affordability (see Appendix Table 6). The following are the selected indicators that serve as a metric for the affordability dimension: AF-1: crude oil price; AF-2: gas price; $\mathrm{AF}-3$ : coal price; $\mathrm{AF}-4$ : electricity (retail) price.

The metric represents the economic dimension in terms of the country's expenditures on energy imports and energy prices for a group of technologies. We used energy prices as an index to represent and interpret the affordability dimension that reflects the country's economic ability to access energy resources at a reasonable price. Due to the lack of electricity retail price data from the year 2000 to 2013, we assumed the electricity price for this period based on a comparative study of water and electricity tariffs by
Hyani (2012), and the electricity distribution tariffs for the household among different cities were equivalent to 0.80 MAD (excluding VAT 14\%) for the first band (0-100 $\mathrm{kWh}$ ) in 2012. However, in 2014, the Ministry of General Affairs and Governance has set new electricity prices, creating six band tariffs for monthly consumption, with its implementation valid for 4 years (MAGG 2014). The study observed that the electricity price for household electricity consumption remained below $100 \mathrm{kWh} / \mathrm{month}$. Therefore, our chosen household tariff from 2014 was equivalent to 0.90 MAD (excluding VAT 14\%) as shown in Appendix Table 10.

\section{Indicator formulation and data coding}

The selected indicators, the raw data and sources, and the formula used to derive the indicators are explained in Appendix Table 6. The framework's timeframe reflects the changes in Morocco's energy security in the periods before and after the implementation of the NES in 2009. In this study, each of the four dimensions will cover certain key factors determining energy security in Morocco. The constructed energy security indicator system under the A-framework can be used as a model for other countries. It can be modified according to the data availability of relevant case studies.

For each energy security dimension, the indicators were chosen according to their suitability under each A-category and data availability. For each indicator previously listed, the data are collected from 2000 to 2016 and calculated according to each indicator's formula; the results of these calculations are presented in Appendix Table 7, 8, 9, and 10 respectively.

\section{Data normalization}

The indicators values (see Appendix Table 7, 8, 9, 10) were transformed to derive normalized values on a scale of 1-10 based on the minimum and maximum values. The min-max normalization approach (Jiawei 2011) was used by Tongsopit et al. (2016) for linear transformation of data.

$$
A=\frac{X-\operatorname{Min}_{\alpha}}{\operatorname{Max}_{\alpha}-\operatorname{Min}_{\alpha}}
$$

where:

$\begin{array}{ll}\text { A } & \text { normalized value based on original data range } \alpha \\ \mathrm{X} & \text { untransformed indicator. } \\ \alpha & \text { data range of } \mathrm{X} \\ \mathrm{M}_{\not n}^{\rho} \mathrm{D}_{-\alpha} & \text { minimum value in data range } \alpha \\ \mathrm{Max}_{-\alpha} & \text { maximum value in data range } \alpha\end{array}$


By considering $A$ based on a new scale ranging from 1 to 10, $\operatorname{Min}_{\beta}=1$ and $\operatorname{Max}_{\beta}=10$.

The equation, in this case, becomes:

$\frac{X^{\prime}-1}{10-1}=\frac{X-\operatorname{Min}_{\alpha}}{M a \mathrm{x}_{\alpha}-\operatorname{Min}_{\alpha}}$

where:

$X^{\prime}$ : normalized indicator based on the 1-10 scale, therefore,

$X^{\prime}=1+\left(\frac{X-\operatorname{Min}_{\alpha}}{\operatorname{Max}_{\alpha}-\operatorname{Min}_{\alpha}}\right) \times(10-1)$

For indicators of each category that have a direct relationship with the scale, their high values represent a high improvement of energy security. For instance, a larger share of RE in power generation implies higher energy security. However, some indicators have an inverse relationship with the scale; a higher value reflects less energy security. For example, a larger share of energy imports indicates lower energy security. In such a case, the raw score's maximum value is considered the minimum scale value of the related indicator, which is equal to 1 . In contrast, the raw score's minimum value indicates the maximum value that is equal to 10 on the scale.

Therefore, the equation for the inverse normalization appears in the following shape:

$X^{\prime}=1+\left(\frac{X-\operatorname{Max}_{\alpha}}{\operatorname{Min}_{\alpha}-\operatorname{Max}_{\alpha}}\right) \times(10-1)$

\section{Data plotting in rhombus grid}

The Morocco energy security status is represented in four time spans from 2000 to 2016 to assess changes that followed the establishment of the NES road map since 2009.
After data coding, the average ordinal values are interpreted in four rhombuses. The rhombuses contain four corners. Each corner reflects one of the four dimensions of energy security. The rhombus plots are compared using the following criteria (Tongsopit et al. 2016):

- Distance to the corners: When the plotted value moves closer toward the corner, it indicates that the energy security status is more robust for a specific dimension in a particular period.

- Area: When the rhombus area gets larger, this implies that the energy security status is higher in the related dimension for a particular period.

The data is assessed based on the normalized indicators to interpret the improvement of each A-dimension.

\section{Results and discussions}

\section{Morocco's energy security: status and multi-dimensional analysis}

Availability From 2000 to 2016, Morocco's energy availability fluctuations can be characterized in three phases. As shown in Fig. 1, during the first 4 years of the analysis, the energy source increased slightly to peak at an average value of 6.82 in 2003, after which it declined sharply from 2003 to hit a low average value of 2.47 in 2008. In 2009, energy sources began to rise slightly but again fell in 2012 to reach the lowest average value of 2.17. During the last 4 years of the analysis, the Moroccan energy sources have experienced ups and downs, showing an unstable trend between 2012 and 2016. This trend can be described in detail by examining the performance of each indicator that composes the availability dimension, including the share of oil import in oil supply, gas import in gas supply, coal import in coal supply, RE in

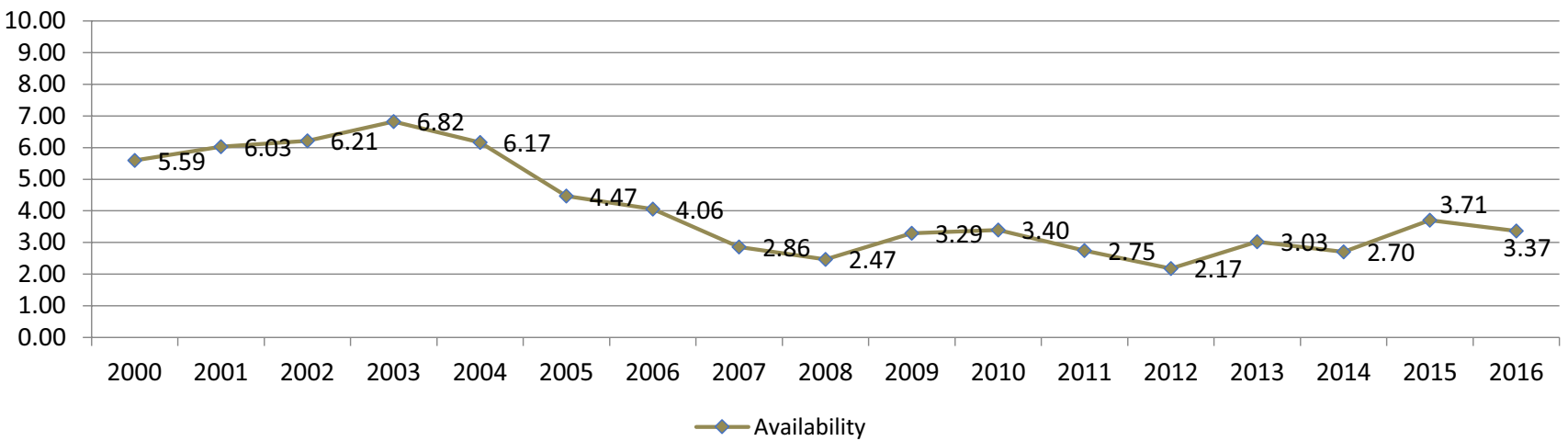

Fig. 1 Availability metric for Morocco from 2000 to 2016 
power generation, $\mathrm{PSH}$ in power generation, and electricity imports in total electricity supply; they are all described in Table 1.

The Moroccan energy mix is mostly dominated by oil. The share of oil imports in the oil supply increased between 2000 and 2011 due to the rapid increase in oil consumption after 2000. The share then dropped as a result of phasing out fuel subsidies from 2013 to 2015 . However, it increased again in 2016 after the shutdown of "Samir," the Moroccan refinery company, which caused an increase in the importation of refined products from abroad.

There was no importation of natural gas by Morocco during the first 5 years of the analysis, indicating a high score between 2000 and 2004, as shown in Table 1. However, from 2005, the country started to import natural gas and implemented the first combined cycle gas turbine (CCGT) plant at "Tahaddart" with nearly 384 megawatts of electricity (MWe). A continuous rise in the use of gas after 2009 was observed. This resulted from the completion of the second CCGT plant in "Ain Beni Mathar" with a capacity of 452 MWe combined with a solar thermal power plant with a capacity of $20 \mathrm{MW}$. In 2017, both CCGT plants reached $5.9 \mathrm{TWh}$ in power generation, equivalent to $18 \%$ of the total electricity generation. Thus, the growth of Morocco's gas imports from 2005 to 2016 can be explained by an increase in electricity generation due to the growing electricity demand. A large amount of gas went to the power sector while other sectors like the industrial, commercial, and household had a low level of gas consumption due to low domestic production. Therefore, the share of gas in the Morocco energy mix remained low by international standards (IEA 2019).

As in many other countries, the survival of the coal mining industry is threatened by many global factors. In Morocco, the coal production has declined in 2000, due to "Jerrada" mining company was sent to a shutdown as a result of technical and economic reasons (Berrada 2018). After 2000, Morocco started depending on coal imports to meet the need of its electricity demand, which accounted for nearly all coal consumption in the country. Table 1 shows a decreasing score in the share of coal imports in coal supply from 2002 to 2007 due to the gradual increase in coal imports, which stabilized between 2008 and 2016, indicating a balanced score. The share of renewable energy in the energy supply, including wind, solar, and hydro, remained low from 2000 to 2009 because Morocco relied only on hydro as renewable energy. It then showed a gradual increase from 2009 to 2016, indicating higher performance. This increase was accompanied by the National Energy Strategy launched in 2009 to integrate a higher share of renewable energy from wind, solar, and hydro in the energy mix. The share of hydro generation dropped

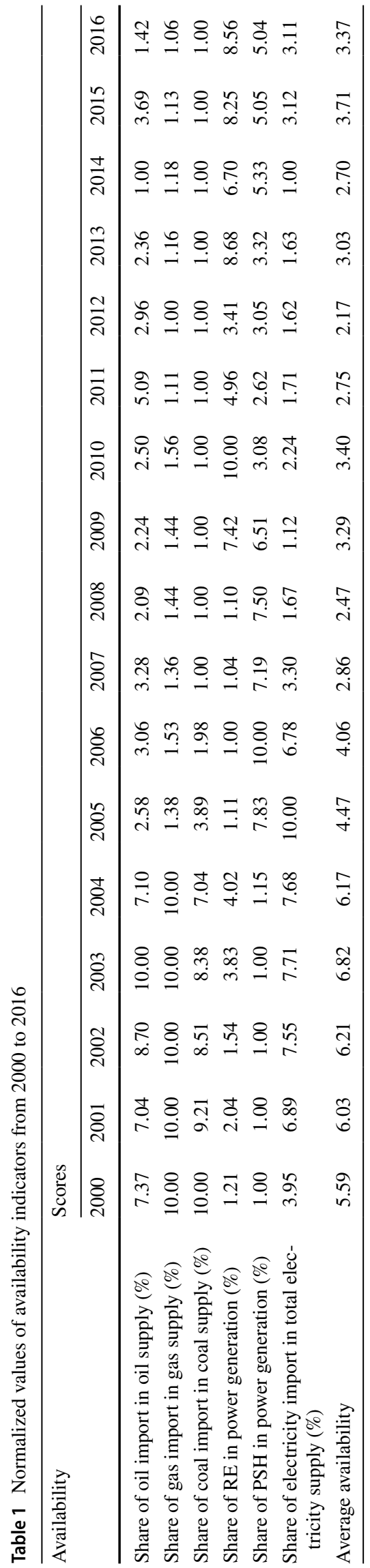


from a higher value in 2010 to a low value in 2012 due to the annual rainfall volatility (IEA 2019).

The share of PSH (pumped storage hydro power) in power generation was absent during the first 4 years. It started to appear in 2005 to support the integration of variable wind and solar PV generation into the power system and balance the power supply.

The share of electricity imports gradually increased from 2006 to 2016, playing an essential role in balancing Morocco's power supply during the high peak. According to IEA (2019), the net import increased from 2 TW to 5.3 TWh during the last 10 years of the study period, accounting for $14 \%$ of the total electricity supply in 2016 . This can be explained by the rapid yearly growth in electricity demand.

Applicability Morocco's energy applicability fluctuates from 4.49 to 6.18 from 2000 to 2016, as shown in Fig. 2. The fossil fuel power plant consumption is presented in Table 2 . Fossil fuel consumption recorded a significant increase between 2000 and 2016 due to the high rise in electricity production due to high demand. The highest input of fossil fuel consumed in power plants was recorded in 2009 and 2010 as compared to other years.

Electricity production efficiency experienced a gradual improvement from 2001 to 2006, but then started to slump from 2007 and hit the lowest value in 2009. It is observed that electricity production efficiency began to recover slightly after 2011 to reach a high-performance score in 2016. This trend can be explained by the implementation of the energy efficiency policy in 2011, according to law $n^{\circ} 47-09$ (Kousksou et al. 2015a, b) to reduce energy consumption. This, in turn, had a significant impact on electricity production efficiency.

Fossil fuel consumption in electricity production is described in Table 2. The fossil fuel consumption in electricity production, including RE technologies, had a low performance from 2000 to 2008 . Following the implementation of NES in 2009, the highest performance production score of 10 was reached in 2010. This indicates the importance of RE technologies in reducing the heavy reliance on fossil fuels and enhancing electricity production at a reasonable cost.

To date, indigenous productions have been negligible; however, the oil and gas exploration program directed by the National Office of Hydrocarbons and Mines (ONHYM 2020) has been promoting upstream investments. Between 2000 and 2018, around 94 wells were drilled in Morocco, including 78 wells onshore and 16 wells offshore. Among the wells drilled onshore, 52 were drilled in the "Gharb" Basin, 31 of which were successful with commercial use hydrocarbons. Table 2 shows the performance of drilling activities from 2000 to 2016 . These activities took an upward trend in 2014 and 2015 reaching a high score of 10 and 9.18 respectively. This was due to ONHYM's promotions and efforts that were rewarded by signing agreements and contracts with several interested companies in oil shale development projects, for instance, ZONATEC in 2012 and Abu Dhabi National Energy Company PJSC "TAQA" and San Leon Energy PLC in 2013. Such security measures were part of the government's plan for its National Energy Strategy to support oil and gas exploration. Improving the level of drilling activities will increase the likelihood of discovering significant reserves that would enhance the country's energy security.

Energy intensity had its highest performance in 2000 with a score of 10, indicating less energy intensity due to less energy consumption. From 2001 to 2016, energy intensity was observed to decrease. Over the study period, the lowest scores of energy intensity were from 2003 to 2005 . This resulted from the steady rise in energy consumption with an average annual growth rate of 5\% during the observed period, reflecting the country's rapid economic growth and the rising population that gained full access to electricity. Morocco saw a gradual decoupling of economic growth and energy consumption in 2007, with a total $9 \%$ reduction in its energy intensity. This resulted in a high score of 7.89 in 2007 and 8.24 in 2008, reflecting better energy intensity than the previous years.
Fig. 2 Applicability metric for Morocco from 2000 to 2016

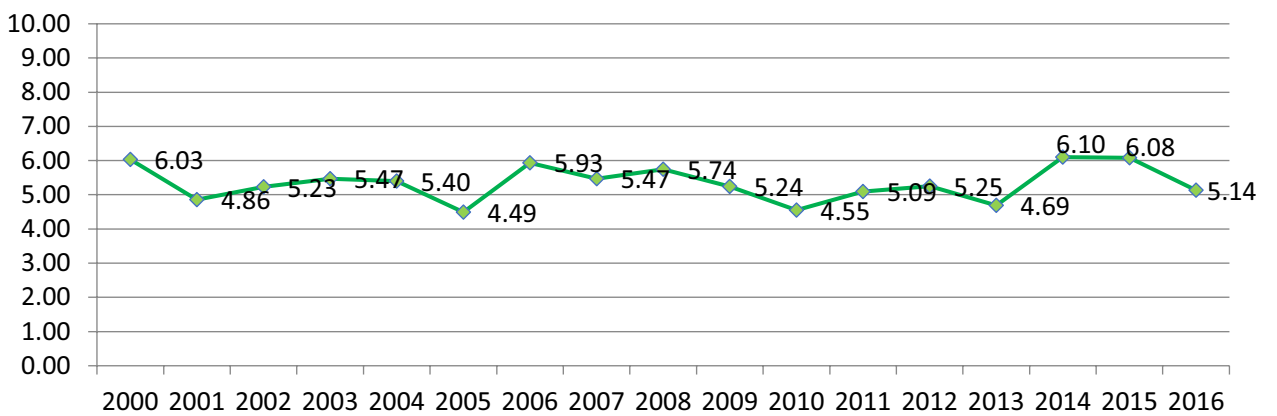

$\prec$ Applicability 
Acceptability The acceptability reflects environmental and social acceptance concerning the impact of the energy sector activities such as energy production and utilization. To evaluate these impacts, we considered the share of renewable energy (RE) in power generation, $\mathrm{CO}_{2}$ emissions per capita, and the share of global $\mathrm{CO}_{2}$ emissions within the acceptability dimension; the higher the normalized scores, the greater the environment and social acceptance of the energy use impacts. Figure 3 and Table 3 show the acceptability scores. Between 2000 and 2004, the average acceptability score took an upward trend to the highest score of 8.01 in 2004. From 2005 to 2009 , the average acceptability score was reasonably stable, after which it fell sharply. The most significant drop occurred in 2014, having a score of 2.90. Later the acceptability performance took a steady path toward 2016 .

The share of RE in power generation remained low between 2000 and 2008 because Morocco was only hydrodependent for its power generation. From 2009 to 2016, the share of renewable started to show a gradual increase. This was accompanied by the launching of NES in 2009 to integrate a higher share of renewable energy from wind, solar, and hydro in power generation.

The highest RE share peaked at an average score of 10 in 2010. This was mainly due to the increased contribution of the share of hydro, which reached $14 \%$ in power generation as hydropower remained the dominant renewable generation source. Between 2011 and 2012, the share of renewable decreased mainly due to the volatility in annual rainfall. Overall, the share of Morocco's renewable energy in power generation slightly increased during the study period, showing that RE generation continued to progress.

The Moroccan energy mix is mostly dominated by fossil fuels, and the population keeps growing along with primary energy consumption. Morocco's fossil fuel $\mathrm{CO}_{2}$ emissions have experienced a steady increase over the period from 2000 to 2016. In 2016, the increase was about $0.52 \%$ as compared to 2015. $\mathrm{CO}_{2}$ emissions per capita in Morocco showed a slight increase in the first few years of the study but remained much lower than other largely populated countries.

The country's $\mathrm{CO}_{2}$ emissions per capita were equivalent to 1.51 tonnes/capita (based on a population of 35,126 296 in 2016), which indicates a decrease of 0.01 compared to 1.52 tonnes/capita in 2015. Table 3 shows that Morocco's energy use per capita had less pollution in the final years of the study period, indicating a slight recovery in acceptability. However, Morocco's economy has remained relatively carbon-intensive due to the high consumption of fossil fuel, mainly in the power generation, transport, and industry sectors. Morocco's GHG emissions are expected to grow at an annual rate of 3.38\%; therefore, though the per capita emissions remain lower due to low energy consumption per capita, it is likely to increase with the increase in energy consumption and population. 
Fig. 3 Acceptability metric for Morocco from 2000 to 2016

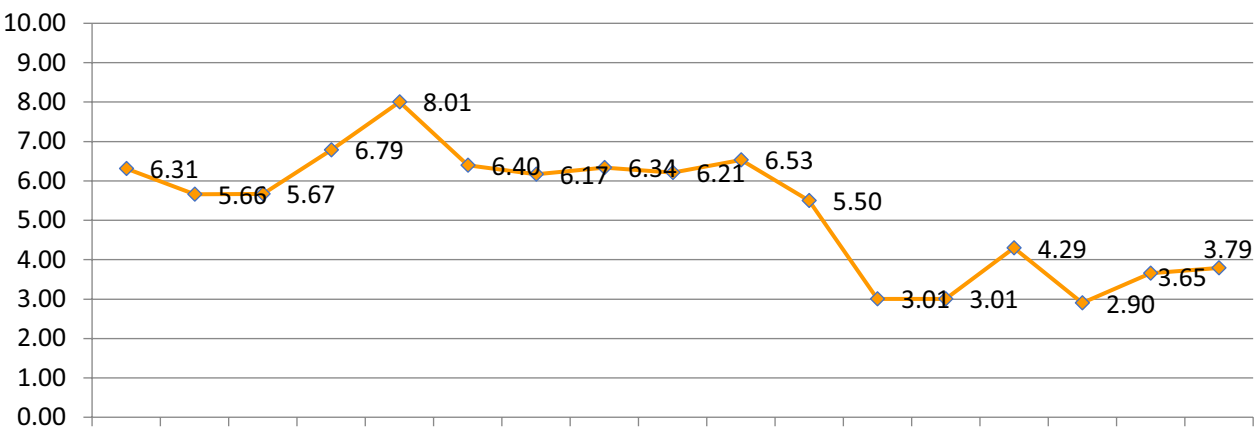

20002001200220032004200520062007200820092010201120122013201420152016
Morocco's global share of $\mathrm{CO}_{2}$ emissions showed less contribution over the study period. The share remained nominal at around $0.15 \%$, a value that is considered low as compared to other emitting countries. Also, with the achievement of the unconditional target $\left(17 \% \mathrm{CO}_{2}\right.$ reduction by 2030), energy-related GHG emissions are expected to only double in 2040 (IEA 2020; EIA 2020). Therefore, Morocco's government will have to promote $\mathrm{CO}_{2}$ mitigation actions, specifically through a higher share of renewable energy and energy efficiency, reducing the carbon intensity in its energy supply to meet its emission reduction targets. Since the power sector is the leading emitter of $\mathrm{CO}_{2}$ emissions, environmentally acceptable resources like wind and solar will contribute substantially to reducing $\mathrm{CO}_{2}$ emissions.

Affordability The affordability is the ability of an economy or population to access energy resources at a reasonable price. Global energy prices such as oil prices are fluctuating due to economic policy uncertainty and geopolitical risk that is the driving force to global stock market movements. To illustrate Morocco's affordability performance, we selected four indicators that reflect the economic dimension in terms of energy prices. The metric includes crude oil prices, gas prices, coal prices, and retail electricity prices. Normalized affordability scores for the study period are presented in Fig. 4 and Table 4. Higher scores indicate greater affordability of energy resources and services.

Affordability showed high volatility due to the fluctuation in crude oil prices, which could not be determined, and the population's full access to electricity, especially after the setup of the PERG program (Global Rural Electrification Program) (Carrasco et al. 2016), which increased the share of the rural population with electricity access to $99.53 \%$ in 2017. The affordability hit its lowest score of 3.63 in 2008 due to the increase in international fuel prices (oil, gas, and coal) in 2008, and second to the lowest in 2014 with 4.31 .

In 2014 , the electricity prices increased compared to previous years according to the government's new regulation for electricity tariffs (MAGG 2014; ONEE 2017). The increase in electricity tariff in 2014 affected the affordability dimension and lowered its performance score to $4.31 \mathrm{com}$ pared to 6.42 in 2013 . The oil price, which was observed to increase between 2011 and 2013, affected the affordability dimension score in 2014. To reduce GHG emissions and encourage the more efficient use of energy, the government made an effort to phase out fossil fuel subsidies from 2013 to 2015. However, the international drop in oil prices in 2014 helped to stabilize the fuel price in Morocco. As a result, the affordability was later observed to recover slightly, reaching a higher score of 6.7 in 2016.

Overall, Morocco's affordability performance improved due to the maintenance of energy prices, mainly for butane gas and electricity for low-income households, through subsidies. This improvement is not likely to be sustainable in the long run due to the significant strain on the national budget. Therefore, a systematic shift toward cheap indigenous energy sources such as solar and wind will be needed to sustain the country's affordability performance. With this in mind, the National Agency for Energy Efficiency (AMEE) considered the deployment of electric cooking based on distributed PV (on and off-grid) in a corporation with an EUsupported project with the IEA.

\section{Morocco energy security trend}

\section{Assessment of balance}

Due to the need for the availability of energy sources to meet the energy demand and the requirement of applicable technologies to deliver this energy to the end-users, the availability and applicability dimensions are treated as having equal weight to identify the security in the energy supply. Considering the social and environmental impacts concerning health and air quality, availability, and applicability alone cannot determine energy supply security. Therefore, acceptability is highlighted as $\mathrm{CO}_{2}$ emissions result from excessive use of coal in the Moroccan power plants. Besides, 
the affordability of energy by the population is also of equal importance. As a result, all indicators of the A-dimensions bear the same weight in this study.

Giving equal importance to each energy security dimension, this study provides a systematic framework for evaluating energy security and treats all components fairly. This is a better way than merely considering energy availability as the core determinant of energy security as stated in classical literature, therefore expanding contemporary literature and incorporating existing analysis (Kruyt et al. 2009; Yao and Chang 2014; Tongsopit et al. 2016).

\section{Rhombus analysis}

The total accumulative areas of each dimension for the entire study period (2000-2016) are presented in Fig. 5, which shows the status of relevant energy security for each period using rhombuses. The overall energy security trends for Morocco from 2000 to 2016 are measured using the rhombus area parameter. Table 5 describes the calculated area of each rhombus that quantifies energy security in Morocco. Each rhombus area illustrates the status of energy security on the four dimensions: the availability of energy resources, applicability of energy technologies, acceptability of energy resources, and affordability of energy resources. Morocco's energy security status under the 4-As framework from the year 2000 to 2016 is illustrated in Fig. 5. The four dimensions of energy security are plotted on a 4-point radar chart, creating a rhombus for four time spans. The total rhombus area shows an increase between 2000 and 2004, then a decline from 2005 to 2016. This indicates that Morocco's energy security had the highest performance during 2000-2004 and then worsened from 2005 to 2016. Morocco's energy security performance was best in the year 2003 and most deficient in 2014.

\section{Discussion}

The proposed set of indicators for Morocco under the 4-As framework provides the country with a holistic paradigm toward achieving its energy security. We found that all four dimensions showed a good performance, reflecting a high status of Morocco's energy security in the first 5 years of the study. This was mainly due to the great performance of the acceptability and affordability index. Excluding the imported gas that was absent from the total energy import in the first period of the study, the energy bills of imported oil and coal were quite affordable. Also, the electricity tariffs for households were reasonable due to the government's price regulations to keep the price below the actual cost of generation. The energy resources were, therefore, affordable, environmentally, and socially acceptable in Morocco. 


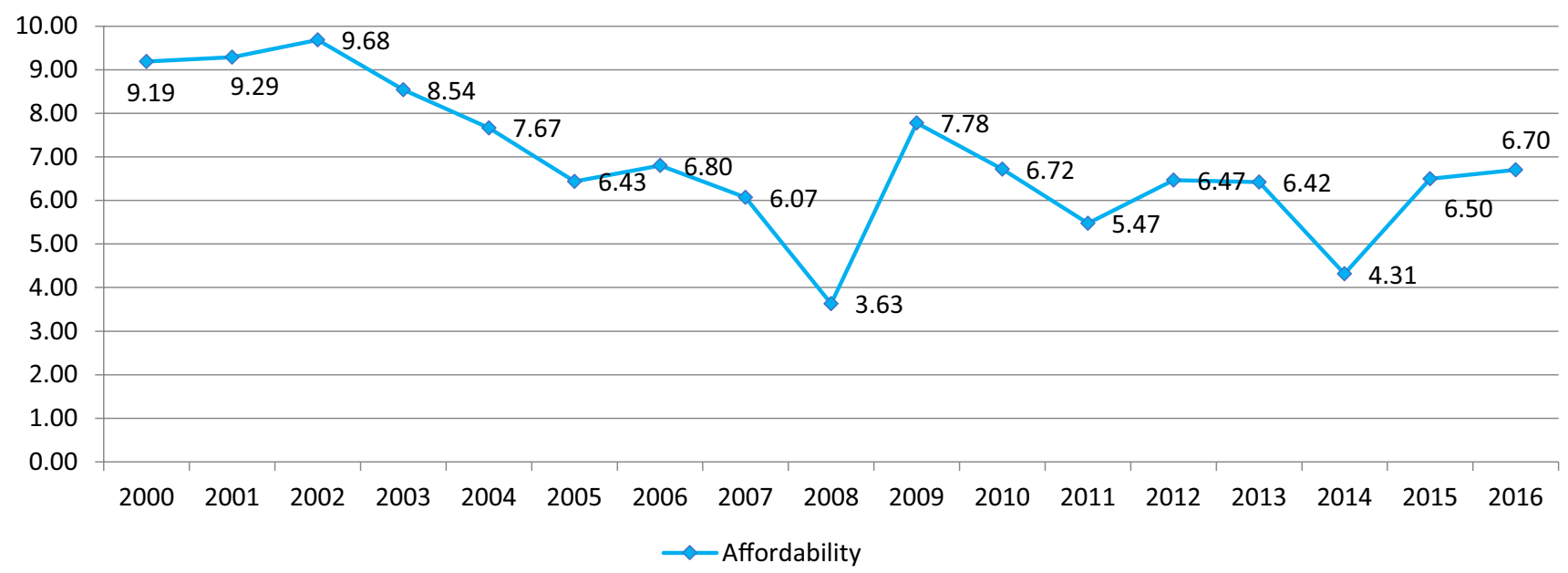

Fig. 4 Affordability metric for Morocco from 2000 to 2016

For the second period of our study, though the applicability and acceptability dimensions were observed to remain constant, the availability and affordability of the energy resources decreased. This decline can be attributed to the increase in energy prices internationally, making energy resources unaffordable. With the energy imports becoming unaffordable, the availability of resources dropped.

In the third period, the implementation of NES-2009 along with government subsidies on fossil fuel aided in the slight recovery of the affordability of energy resources. However, availability and acceptability decreased. This is mainly attributed to the increase in $\mathrm{CO}_{2}$ emissions due to more demand for energy consumption, which further led to increased importation of fossil fuel, especially coal and gas.

The last period in our study revealed a slight increase in availability due to the government's efforts to stabilize the country's energy availability by promoting renewable generation. However, even with the setting of price regulations in 2014, the affordability and acceptability took a downward turn as the electricity tariffs in Morocco increased with a continued rise in energy consumption. Finally, the applicability was observed to remain relatively constant throughout the whole study period.

\section{Conclusions and policy implication}

This study addressed the changes in Morocco's energy security status from 2000 to 2016 using the rhombus area analysis. The rhombus areas for the four periods were decreased, indicating a decline in Morocco's energy status. It was observed that Morocco's energy security status was highest in the first period and gradually deteriorated in the last three periods of the study. The rhombus area analysis provided a full guide to uncover the factors that impacted Morocco's energy security status. In this study, Morocco's energy system was observed facing a lot of challenges that threaten the security of the energy supply. The low availability of endogenous resources continues to increase the country's reliance on external resources. This was further making the country vulnerable to the fluctuation in energy prices and the disruption in supply. For Morocco to overcome all these challenges and reverse its downward energy security trend toward sustainable economic growth and low-carbon transition, our study suggests the need of implementing the following set of policy instruments. Therefore, the government should accelerate clean energy transitions by integrating a higher share of renewable energy and promoting energy efficiency initiatives. This can be achieved by fostering green investments, providing financial incentives in subsidies and tax relaxations, simplifying contracts' legal procedures for propagating startup renewable energy projects that help boost the energy supply. Accelerating applicable green technologies and innovations for scaling up renewable beyond the power sector needs also to be considered to drive sustainable domestic cooling and heating, transport, and water management. Diversifying energy sources through injecting a higher share of abundant solar and wind energy into the energy mix will also bring significant benefits to the country's energy security and help achieve emission reduction targets. Besides, international and regional energy partnerships should be developed by establishing links with European and African energy markets and building necessary infrastructures to secure the future of integrated renewables into the energy mix.

The findings from this study also show that the country is highly dependent on external energy sources. The energy prices were not stable during the last two periods of the study, especially for oil, which is still playing a significant role in the country's energy mix. This provides a strong 


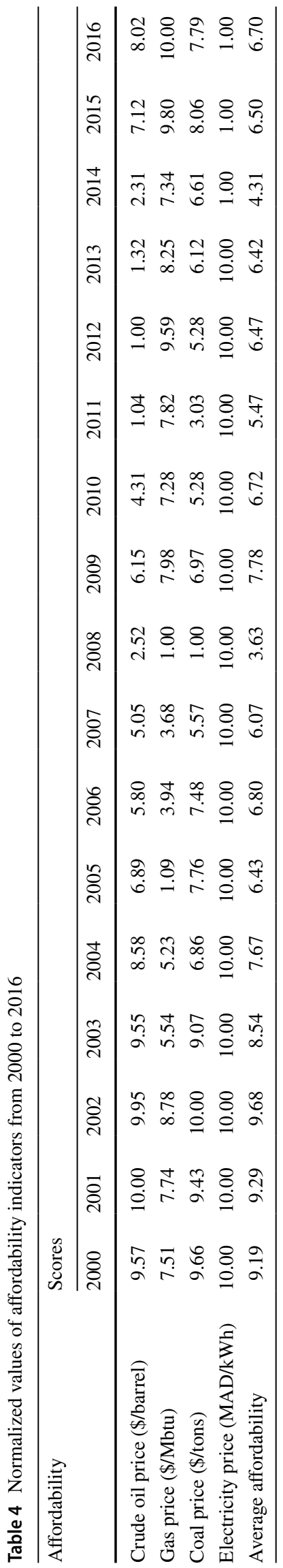

justification for Morocco to minimize its demand for oil imports and strengthen its domestic oil and gas exploration program. This is so crucial to manage the risk from remaining import-dependent.

The applicability dimension remained nearly unchanged throughout the whole study period, according to our findings. This shows a lesser effort to incorporate new technologies that help improve energy efficiency, both in terms of fossil fuel and renewable energy. The need to address the environmental objectives by evaluating technology options and policy measures under a long-term low-carbon development strategy is crucial from these findings. Creating a more potent synergy between science, policy, and business in renewable energy and energy efficiency is essential in improving Morocco's energy security and achieving sustainable energy transition.

Given the serious fact of climate change and environmental risks that may hamper future investments, promoting green finance in the energy sector is an essential part of the country's effort to combat climate change and meet sustainable development goals. To allow resources to flow to low-carbon sectors, the Moroccan government should boost green finance as well as green investment. During the transition to a low-carbon economy, financial institutions must be able to identify environmental risks and ensure financial stability by integrating climate change risks in their risk management strategies and governance structures, disclosing sufficient information about environmental performance and progress between governments and businesses to help minimize financial risks. Market and policy are both key players that can work together to promote green finance; market can play a significant role in determining resource allocation priorities that favor the low-carbon transition. Meanwhile, policies can incentivize the use of green finance instruments such as green bonds, green banks, and carbon pricing to finance climate change adaptation projects for sustainability outcomes and investors' returns.

This study has assessed energy security in Morocco from an economic, technological, and environmental point of view, with a focus on scaling up the use of renewable energy to achieve energy security and low-carbon transition. Howsoever, our study has some limitations in terms of addressing energy storage as an essential aspect to deal with renewable energy intermittency. Therefore, further innovative researches on energy storage technologies, particularly green batteries, could be maximized to match the fast-growing electricity demand with intermittent supply and accelerate the low-carbon transition as well as sustainably decarbonize the electricity grid.

This study has used a multidisciplinary framework that is universal and, as such, is usable by any country. As the energy demand pattern varies from country to country, the indicators used may be reduced or expanded to assess any country's energy security better. 
Fig. 5 Trends in Morocco's energy security across the four dimensions from 2000 to 2016
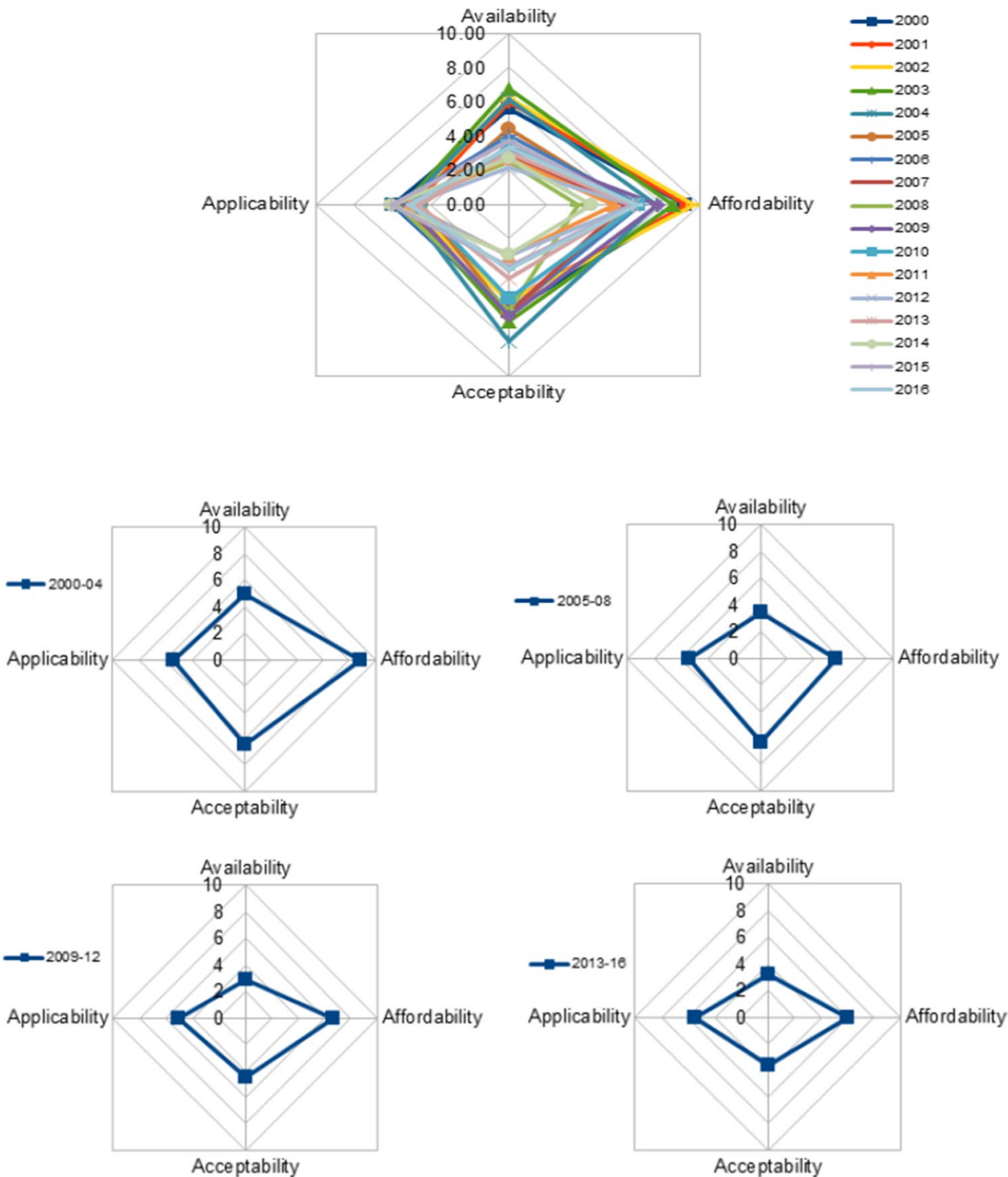

Table 5 Average normalized values of the 4-As, energy security, and areas of rhombuses

\begin{tabular}{|c|c|c|c|c|c|c|c|c|c|c|c|c|c|c|c|c|c|}
\hline & 2000 & 2001 & 2002 & 2003 & 2004 & 2005 & 2006 & 2007 & 2008 & 2009 & 2010 & 2011 & 2012 & 2013 & 2014 & 2015 & 2016 \\
\hline Availability & 5.59 & 6.03 & 6.21 & 6.82 & 6.17 & 4.47 & 4.06 & 2.86 & 2.47 & 3.29 & 3.40 & 2.75 & 2.17 & 3.03 & 2.70 & 3.71 & 3.37 \\
\hline Applicability & 6.03 & 4.86 & 5.23 & 5.47 & 5.40 & 4.49 & 5.93 & 5.47 & 5.74 & 5.24 & 4.55 & 5.09 & 5.25 & 4.69 & 6.10 & 6.08 & 5.14 \\
\hline Acceptability & 6.31 & 5.66 & 5.67 & 6.79 & 8.01 & 6.40 & 6.17 & 6.34 & 6.21 & 6.53 & 5.50 & 3.01 & 3.01 & 4.29 & 2.90 & 3.65 & 3.79 \\
\hline Affordability & 9.19 & 9.29 & 9.68 & 8.54 & 7.67 & 6.43 & 6.80 & 6.07 & 3.63 & 7.78 & 6.72 & 5.47 & 6.47 & 6.42 & 4.31 & 6.50 & 6.70 \\
\hline Avg. energy security & 6.78 & 6.46 & 6.70 & 6.90 & 6.81 & 5.45 & 5.74 & 5.18 & 4.51 & 5.71 & 5.04 & 4.08 & 4.22 & 4.61 & 4.00 & 4.98 & 4.75 \\
\hline Area (Sq. unit) & 59.58 & & & & & 44.34 & & & & 33.56 & & & & 29.82 & & & \\
\hline
\end{tabular}




\section{Appendix}

Table 6 Specification of energy security indicators

\begin{tabular}{|c|c|c|c|c|}
\hline Indicator & Row data & Unit of measurement & Formula & Data source \\
\hline \multicolumn{5}{|l|}{ Availability } \\
\hline $\begin{array}{l}\text { Share of oil import in oil } \\
\text { supply }\end{array}$ & $\begin{array}{l}\text { Oil import } \\
\text { Total oil supply }\end{array}$ & $\%$ & $\frac{\text { Oil import }}{\text { Total oil supply }}$ & EIA \\
\hline $\begin{array}{l}\text { Share of gas import in gas } \\
\text { supply }\end{array}$ & $\begin{array}{l}\text { Gas import } \\
\text { Total gas supply }\end{array}$ & $\%$ & $\frac{\text { Gas import }}{\text { Total gas supply }}$ & EIA \\
\hline $\begin{array}{l}\text { Share of coal import in coal } \\
\text { supply }\end{array}$ & $\begin{array}{l}\text { Coal import } \\
\text { Total coal import }\end{array}$ & $\%$ & $\frac{\text { Coal import }}{\text { Total coal import }}$ & EIA \\
\hline $\begin{array}{l}\text { Share of RE in power genera- } \\
\text { tion }\end{array}$ & $\begin{array}{l}\text { Total RE generation } \\
\text { Total power generation }\end{array}$ & $\%$ & $\frac{\text { Total RE generation }}{\text { Total power generation }}$ & EIA \\
\hline $\begin{array}{l}\text { Share of PSH in power genera- } \\
\text { tion }\end{array}$ & $\begin{array}{l}\text { PSH generation } \\
\text { Total power generation }\end{array}$ & $\%$ & $\frac{\text { PSH generation }}{\text { Total power generation }}$ & EIA \\
\hline $\begin{array}{l}\text { Share of electricity import in } \\
\text { total electricity supply }\end{array}$ & $\begin{array}{l}\text { Electricity import } \\
\text { Total electricity supply }\end{array}$ & $\%$ & $\frac{\text { Electricity import }}{\text { Total electricity supply }}$ & EIA \\
\hline \multicolumn{5}{|l|}{ Applicability } \\
\hline $\begin{array}{l}\text { Fossil fuel power plant con- } \\
\text { sumption }\end{array}$ & $\begin{array}{l}\text { Total fossil energy consumption } \\
\text { Total electricity Prod. exclud- } \\
\text { ing RE }\end{array}$ & Ktoe/GWh & $\frac{\text { Total fossil energy consumption }}{\text { Total electricity production excluding RE }}$ & EIA \\
\hline $\begin{array}{l}\text { Electricity production effi- } \\
\text { ciency }\end{array}$ & $\begin{array}{l}\text { Total electricity production } \\
\text { Total energy input }\end{array}$ & $\mathrm{GWh} / \mathrm{K}$ toe & $\frac{\text { Total electricity production }}{\text { Total energy input }}$ & EIA \\
\hline $\begin{array}{l}\text { Fossil fuel consumption in } \\
\text { electricity production }\end{array}$ & $\begin{array}{l}\text { Total fossil energy consumption } \\
\text { Total electricity production } \\
\text { including RE }\end{array}$ & Ktoe/GWh & $\frac{\text { Total fossil energy consumption }}{\text { Total electricity production including } \mathrm{RE}}$ & EIA \\
\hline $\begin{array}{l}\text { No. of exploratory wells drilled } \\
\text { for oil and gas }\end{array}$ & No. of exploratory drilled wells & \# & $\begin{array}{l}\text { No. of exploratory wells drilled } \\
\text { for oil and gas }\end{array}$ & ONHYM \\
\hline \multirow[t]{2}{*}{ Energy intensity } & $\begin{array}{l}\text { Total primary energy consump- } \\
\text { tion }\end{array}$ & Btu & $\frac{\text { Total primary energy consumption }}{\text { GDP }}$ & EIA \\
\hline & GDP & GDP IC \$, PPP & & WDB \\
\hline \multicolumn{5}{|l|}{ Acceptability } \\
\hline $\begin{array}{l}\text { Share of RE in power genera- } \\
\text { tion }\end{array}$ & $\begin{array}{l}\text { RE power generation } \\
\text { Total power generation }\end{array}$ & $\%$ & $\frac{\text { RE power generation }}{\text { Total power generation }}$ & EIA \\
\hline $\mathrm{CO}_{2}$ emissions per capita & $\begin{array}{l}\mathrm{CO}_{2} \text { emissions } \\
\text { Population }\end{array}$ & $\begin{array}{l}\text { Tonnes } \\
\text { Million }\end{array}$ & $\frac{\text { Morocco } \mathrm{CO}_{2} \text { emission }}{\text { Morocco population }}$ & EIA \\
\hline Share of global $\mathrm{CO}_{2}$ emissions & $\begin{array}{l}\mathrm{CO}_{2} \text { emissions } \\
\text { Global } \mathrm{CO}_{2} \text { emissions }\end{array}$ & $\%$ & $\frac{\text { Morocco } \mathrm{CO}_{2} \text { emission }}{\text { Global } \mathrm{CO}_{2} \text { emission }}$ & EIA \\
\hline \multicolumn{5}{|l|}{ Affordability } \\
\hline Crude oil price & Europe Brent spot price FOB & $\$ /$ barrel & Europe Brent spot price FOB & Wind database \\
\hline Gas price & Henry Hub natural gas spot price & \$/Mbtu & Henry Hub natural gas spot price & Wind database \\
\hline Coal price & Coal price & $\$ /$ tons & Coal price & Wind database \\
\hline Electricity retail price & Progressive tariff-band 1 & MAD/kWh & Progressive tariff-band 1 & MAGG /ONEE \\
\hline
\end{tabular}



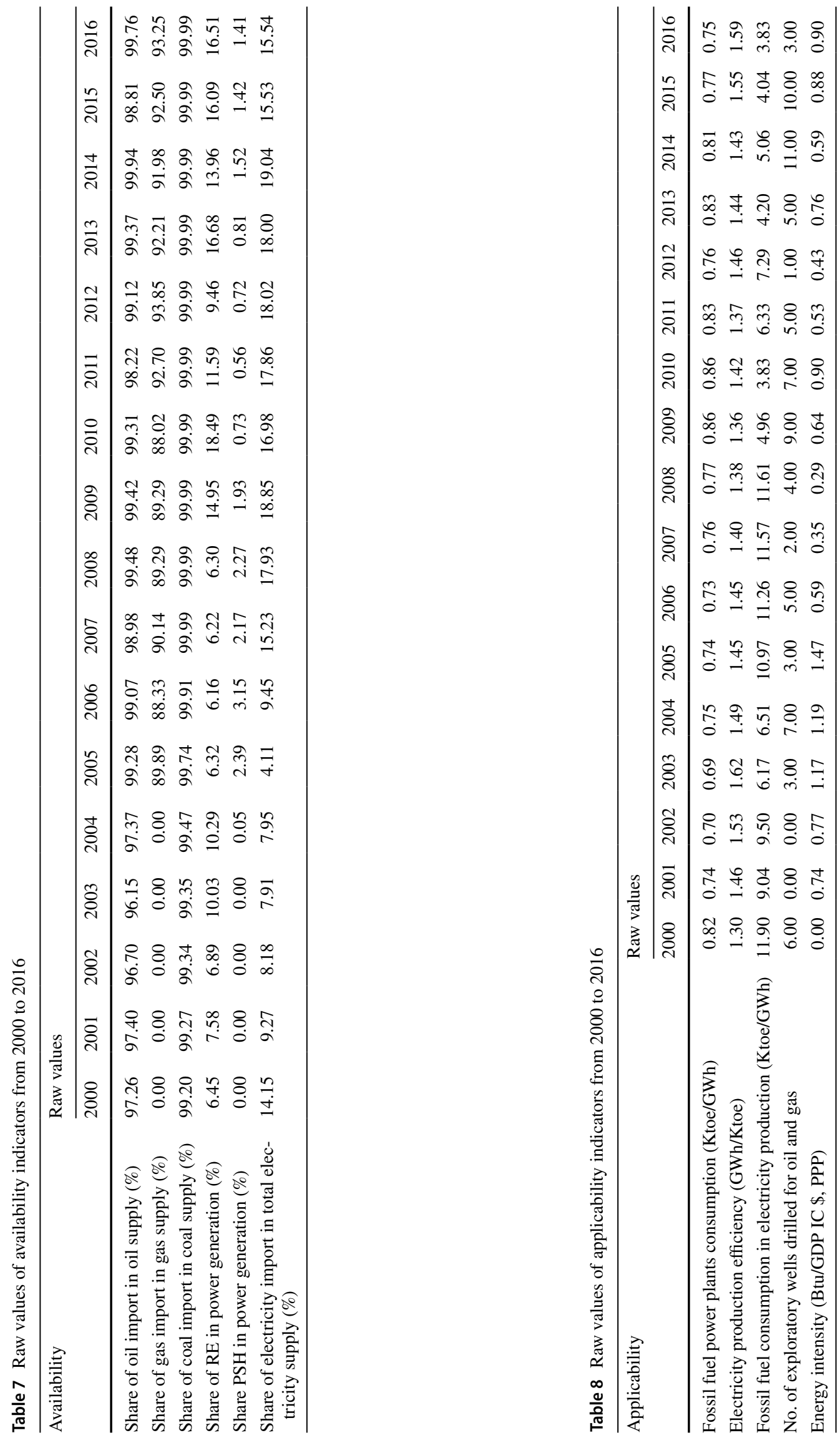


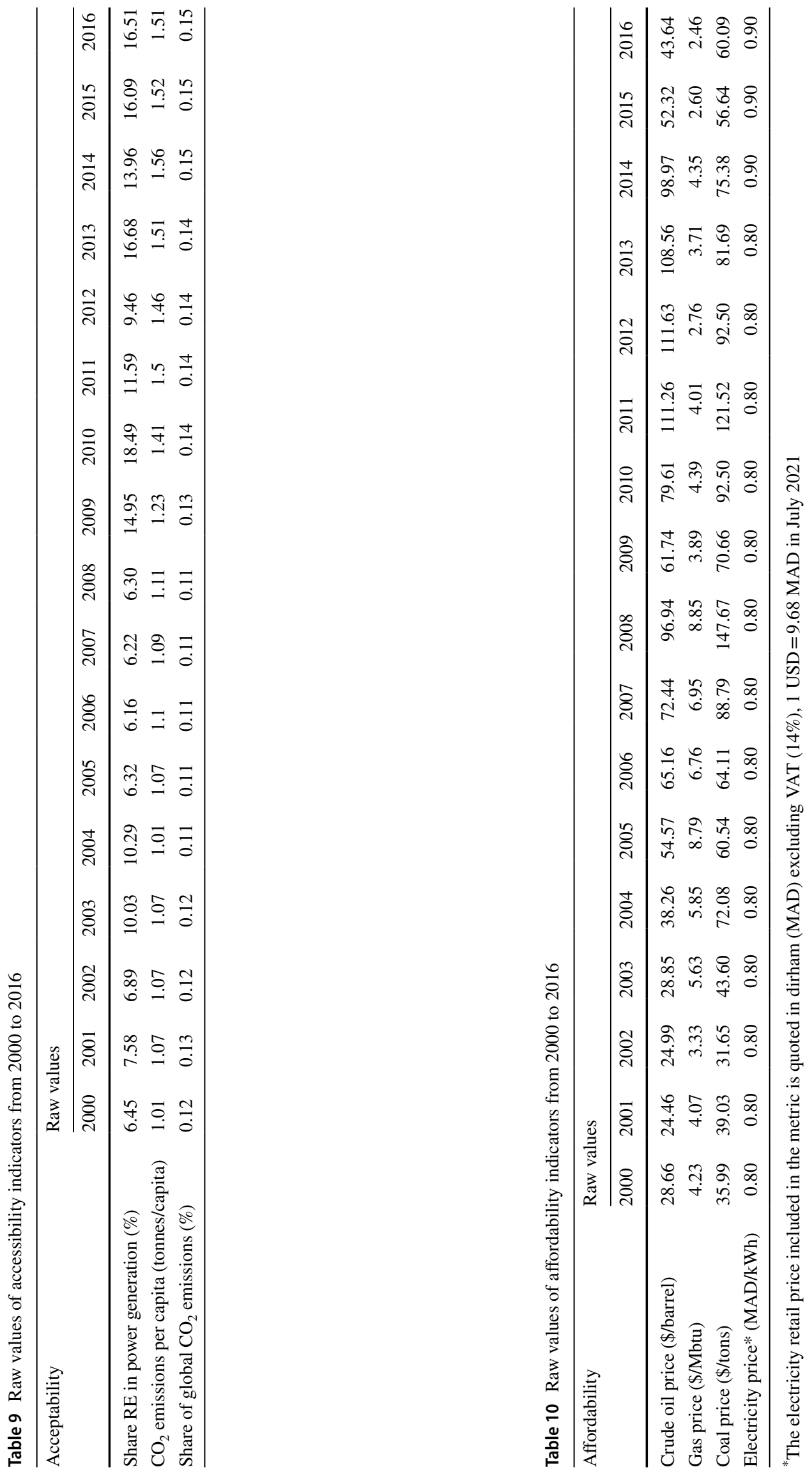


Author contribution Fatima Zahra Ainou: conceptualization, data curation, formal analysis, investigation, methodology, writing-original draft. Mohsin Ali: methodology and review. Muhammad Sadiq: original draft and editing.

Data availability All the tables and figures are made by the author. The data was taken from International Energy Agency (EIA), Energy Information Administration (EIA), World Data Bank (WDB), The National Office of Hydrocarbons and Mines (ONHYM), The Ministry of General Affairs and Governance, The National Agency for Electricity and Water (ONEE), and Beijing Institute of Technology (wind database). The data used in this paper can be obtained from the authors upon request.

\section{Declarations}

Ethics approval and consent to participate Not applicable.

Consent for publication Not applicable.

Competing interests The authors declare no competing interests.

\section{References}

Alemzero DA, Sun H, Mohsin M, Iqbal N, Nadeem M, Vo XV (2021) Assessing energy security in Africa based on multi-dimensional approach of principal composite analysis. Environ Sci Pollut Res 28:2158-2171. https://doi.org/10.1007/s11356-021-14367-7

Ang BW, Choong WL, Ng TS (2015) Energy security: Definitions, dimensions and indexes. Renew Sust Energ Rev 42:1077-1093. https://doi.org/10.1016/j.rser.2014.10.064

Asia Pacific Energy Research Centre - APERC (2007) Quest for energy security in the 21st century: resources and constraints. APERC, Tokyo. https://aperc.or.jp/file/2010/9/26/APERC_2007_A_Quest_ for_Energy_Security.pdf

Berrada K (2018) Jerada beyond the mine, a sustainability approach. https://mipa.institute/wp-content/uploads/2018/09/Berrada-Engli sh.pdf

Carrasco L, Martín-Campo F, Narvarte L, Ortuño MT, Vitoriano B (2016) Design of maintenance structures for rural electrification with solar home systems. The case of the Moroccan program. Energy 117:47-57. https://doi.org/10.1016/j.energy.2016.10.073

Chang Y, Li Y (2015) The Routledge handbook of environmental economics in Asia. Routledge, London, pp 281-306

Colglazier Jr EW, Deese DA (1983) Energy and security in the 1980s. Ann rev energ 8(1):415-449. https://www.annualreviews.org/doi/ pdf/10.1146/annurev.eg.08.110183.002215

Energy Information Administration (EIA). Morocco - Emissions. EIA, Washington, DC. https://www.eia.gov/international/data/country/ MAR/other-statistics/emissions-by-fuel. Accessed 23 Jul 2020

Commission E (2001) Green paper-towards a European strategy for the security of energy supply. Revue de l'Energie, Brussels

Gallagher KS (2006) Limits to leapfrogging in energy technologies? Evidence from the Chinese automobile industry. Energy Policy 34(4):383-394. https://doi.org/10.1016/j.enpol.2004.06.005

Hotelling H (1931) The economics of exhaustible resources. J Polit Econ 39(2):137-175. https://doi.org/10.1086/254195

Hughes L (2012) A generic framework for the description and analysis of energy security in an energy system. Energy Policy 42:221231. https://doi.org/10.1016/j.enpol.2011.11.079
Hyani OE (2012) Comparison of water and electricity tariffs in Morocco. https://www.elhyani.net/comparatif-des-tarifs-deau-etdelectricite-au-maroc/. Accessed 23 Feb 2021.

International Energy Agency - IEA (2019) Ensuring Energy Security. IEA, Paris. https://www.iea.org/areas-of-work/ensuring-energysecurity

International Energy Agency - IEA (2019) Energy Policies Beyond IEA Countries-Morocco. IEA, Paris. https://www.connaissan cedesenergies.org/sites/default/files/pdf-actualites/Energy_Polic ies_beyond_IEA_Contries_Morocco.pdf. Accessed 23 June 2020

International Energy Agency - IEA (2018) Morocco - Key Energy Statistics. IEA, Paris. https://www.iea.org/countries/morocco. Accessed 23 July 2020).

Jiawei HM, Kamber J, Pei, (2011) Data mining: concepts and techniques. Morgan Kaufmann, Waltham

Karakosta C, Marinakis V, Psarras J (2013) RES cooperation opportunities between EU and MENA countries: the case of Morocco. Energy Strategy Rev 2(1):92-99. https://doi.org/10.1016/j.esr. 2013.04.003

Kousksou T, Allouhi A, Belattar M, Jamil A, El Rhafiki T, Arid A, Zeraouli Y (2015) Renewable energy potential and national policy directions for sustainable development in Morocco. Renew Sust Energ Rev 47:46-57. https://doi.org/10.1016/j.rser.2015. 02.056

Kousksou T, Allouhi A, Belattar M, Jamil A, El Rhafiki T, Zeraouli Y (2015) Morocco's strategy for energy security and low-carbon growth. Energy 84:98-105. https://doi.org/10.1016/j.energy.2015. 02.048

Kruyt B, van Vuuren DP, de Vries HJ, Groenenberg H (2009) Indicators for energy security. Energy Policy 37(6):2166-2181. https:// doi.org/10.1016/j.enpol.2009.02.006

Lacher W, Kumetat D (2011) The security of energy infrastructure and supply in North Africa: hydrocarbons and renewable energies in comparative perspective. Energy Policy 39(8):4466-4478. https:// doi.org/10.1016/j.enpol.2010.10.026

Ministry of Energy, Mines, Water and Environment (MEMEE) (2013) Analysis of Energy Indicators.

Moore S (2017) Evaluating the energy security of electricity interdependence: perspectives from Morocco. Energy Res Soc Sci 24:21-29. https://doi.org/10.1016/j.erss.2016.12.008

Morocco (2016) Morocco - Nationaly Determined Contribution under the UNFCCC. https://www4.unfecc.int/sites/ndcstaging/Publi shedDocuments/Morocco\%20First/Morocco\%20First\%20NDCEnglish.pdf

Ministry of General Affairs and Governance - MAGG (2014) New tariff and billing system for electricity, drinking water and sanitation distribution services. http://www.mag.gov.ma/index.php/fr/ les-grands-dossiers/927-contrat-programme-one-2.html. Accessed 12 June 2020

National Agency for Electricity and Water - ONEE (2017) Domestic Use and Private Lighting. http://www.one.org.ma/FR/pages/ interne.asp?esp $=1 \& \mathrm{id} 1=3 \& \mathrm{id} 2=113 \& \mathrm{t} 2=1$. Accessed 16 June 2020.

National Office of Hydrocarbons and Mines - ONHYM (2020) Drilling activity of ONHYM and its partners. http://www.onhym.com/en/ drilling-activity/drilling-activity-of-onhym-and-its-partners.html. Accessed 15 July 2020

Sebitosi AB (2008) Energy efficiency, security of supply and the environment in South Africa: moving beyond the strategy documents. Energy 33(11):1591-1596. https://doi.org/10.1016/j.energy.2008. 08.003

Sovacool BK (2013) An international assessment of energy security performance. Ecol Econ 88:148-158. https://doi.org/10.1016/j. ecolecon.2013.01.019 
Sovacool BK, Mukherjee I (2011) Conceptualizing and measuring energy security: a synthesized approach. Energy 36(8):53435355. https://doi.org/10.1016/j.energy.2011.06.043

Tongsopit S, Kittner N, Chang Y, Aksornkij A, Wangjiraniran W (2016) Energy security in ASEAN: a quantitative approach for sustainable energy policy. Energy Policy 90:60-72. https://doi. org/10.1016/j.enpol.2015.11.019

Trollip H, Butler A, Burton J, Caetano T, Godinho C (2014) Energy security in South Africa. https://media.africaportal.org/docum ents/Energy-Security_in-South-Africa.pdf

Vivoda V (2010) Evaluating energy security in the Asia-Pacific region: a novel methodological approach. Energy Policy 38(9):5258 5263. https://doi.org/10.1016/j.enpol.2010.05.028

Von Hippel D, Suzuki T, Williams JH, Savage T, Hayes P (2011) Energy security and sustainability in Northeast Asia. Energy
Policy 39(11):6719-6730. https://doi.org/10.1016/j.enpol.2009. 07.001

Yao L, Chang Y (2014) Energy security in China: a quantitative analysis and policy implications. Energy Policy 67:595-604. https:// doi.org/10.1016/j.enpol.2013.12.047

Yergin D (1988) Energy Security in the 1990s. Foreign Aff 67(1):110-132

Yergin D (2011) The quest: energy, security, and the remaking of the modern world. Penguin

Publisher's note Springer Nature remains neutral with regard to jurisdictional claims in published maps and institutional affiliations. 